
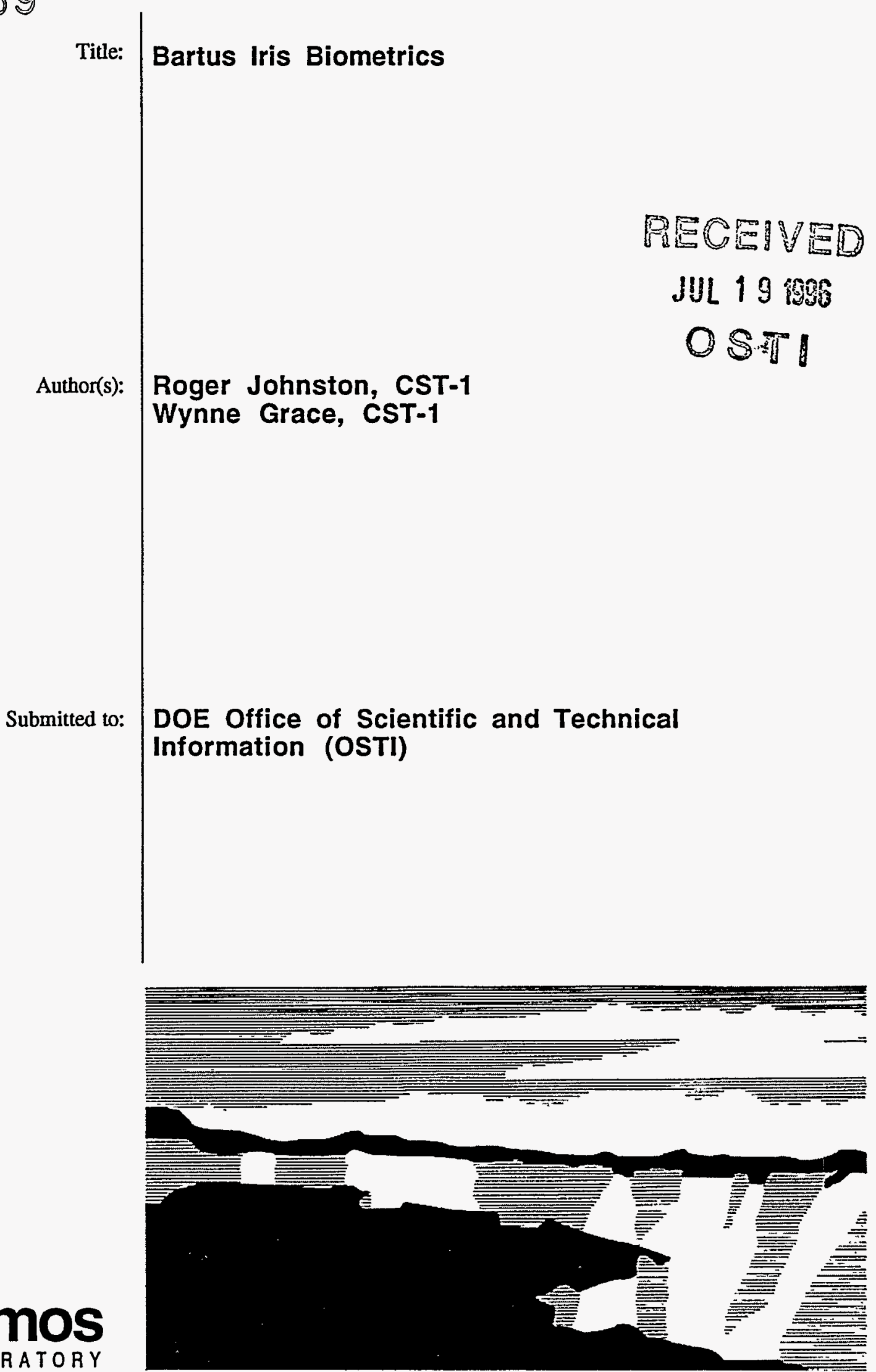

Los Alamos National Laboratory, an affirmative action/equal opportunity employer, is operated by the University of Califomia for the U.S. Department of Energy under contract W-7405-ENG-36. By acceptance of this article, the publisher recognizes that the U.S. Govemment retains a nonexclusive, royaltyfree license to publish or reproduce the published form of this contribution, or to allow others to do so, for U.S. Government purposes. The Los Alamos

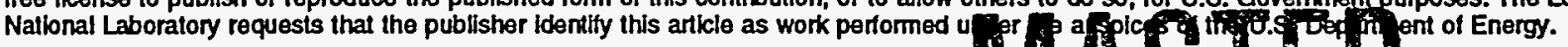




\section{DISCLAIMER}

Portions of this document may be illegible in electronic image products. Images are produced from the best available original document. 


\title{
Bartus Iris Biometrics
}

Roger Johnston* and Wynne Grace

\begin{abstract}
This is the final report of a one-year, Laboratory-Directed Research and Development (LDRD) project at the Los Alamos National Laboratory (LANL). We won a 1994 R\&D 100 Award for inventing the Bartas Iris Verification System. The system has been delivered to a sponsor and is no longer available to us. This technology can verify the identity of a person for purposes of access control, national security, law enforcement, forensics, counter-terrorism, and medical, financial, or scholastic records. The technique is non-invasive, psychologically acceptable, works in real-time, and obtains more biometric data than any other biometric except DNA analysis. This project sought to develop a new, second-generation prototype instrument.
\end{abstract}

\section{Background and Research Objectives}

We received a 1994 R\&D 100 Award for the invention of the Bartas Iris Verification System. The instrument is named for Seigneur du Bartas, the French poet who first called the eyes "the windows of the soul." The concept actually dates to 1885 when Alphonse Bertillon first proposed using iris colors and patterns to identify people $[1,2]$. The idea has reappeared several times during the 1960's, 1970's, and 1980's [3,4], but has not previously been demonstrated or implemented.

The Bartas Iris Verification System verifies the identify of people based on video images of the externally visible iris, the colored part of the eye. It does this by analyzing the extremely complex iris patterns and markings that are unique to each person [3-13]. (Even identical twins have different iris patterns.) Iris patterns become permanent after adolescence and do not change with time or stress. They change very little with injury or disease. The pattern for a person's left eye differs from that for his/her right.

Iris patterns are the result of a complex meshwork of melanocyte and fibroblast cells $[3,8,10]$. The density and pigmentation of this meshwork vary across the iris, forming a complex pattern that becomes permanent at puberty $[3,6,8,12]$. Iris color depends on the density of cells and on the concentration of pigment. Brown eyes have a high density of cells

*Principal investigator, e-mail: roger_johnston@lanl.gov 
and a large amount of pigmentation. Blue, gray, hazel, and green eyes have lower densities and less pigmentation. The meshwork pattern on an iris can be interrupted by permanent markings such as freckles or nevi [7-13]. Freckles are flat spots on the iris caused by localized accumulations of pigment in melanocyte cells. Nevi are discrete, elevated dark masses of cells.

Potential applications for the Bartas Iris Verification System include protecting controlled-access sites such as government, military, corporate, financial, medical, day care, and laboratory facilities. Protection of legal, financial, military, scholastic, or medical records is another area of use. Iris biometrics may also prove to be valuable tools for law enforcement, border and customs control, counter-terrorism efforts, and forensic identity confirmations after catastrophic accidents. Iris patterns might also be used to check the identity of certain species of animals; this is important, for example, for special show or breeding animals, or for rare species released back into the wild by environmentalists.

Iris biometrics have a number of important advantages over other biometric techniques, including commercial retinal scanning systems. These include:

- Much higher information content than any other biometric, except DNA analysis.

Identification is thus possible, not just verification. (Identification involves determining the identity of a person, based solely on his/her iris and a search of the entire database of iris patterns. Verification, in contrast, involves comparing the person's iris patterns with only one pattern on record to make a yes-no decision about whether the person is who he/she claims to be; for verification, a person must present a security badge, personal identification number, or password, in addition to his/her iris.)

- Video iris verification occurs in real-time, unlike DNA analysis.

- The system is remote and highly non-invasive.

- Psychological acceptance is much higher than other biometric techniques, such as retinal scanning. (The iris system uses a familiar video camera; there is no scary hightech looking equipment; the person is in charge of the verification procedure and is not touched; the eye is kept at least seven inches from a podium containing the equipment; safety and perceived safety are very high.)

- Privacy and legality issues with iris patterns may be simpler and more advantageous than for other biometric techniques.

- Work to date suggests we can deal successfully with most or all counter-measures such as contact lenses and drug-induced pupil dilation.

- Verification/identification of moving people is at least theoretically possible.

- It should be possible to digitize high-quality photographic film images of people's faces to provide video iris patterns. 
- It may be possible to detect when an individual is intoxicated by alcohol or a dozen other drugs based on abnormalities in the pupil and in eye responses. The "rapid eye test" $[14,15]$, when performed manually by trained medical personnel, detects intoxication with a reported $95 \%$ accuracy rate [14-21]. It may be possible to automate this test by modifying the Bartas Iris Verification System. Users of biometrics for the purpose of access control may want to prevent intoxicated persons, even if authorized for entry, from gaining access to their facilities. Pilots, truck drivers, and train engineers could potentially be screened for intoxication prior to assuming their duties in a rapid, non-invasive manner.

- Other possible applications: Eye abnormalities are often present in people with mental disorders [22-24] or who are lying or severely stressed [25,26].

The goal of the project was to produce a second-generation, improved unit for performing iris biometrics. We delivered our only prototype instrument to the United States Secret Service in October. Since then, we are not able to demonstrate the instrument or improve its performance. This new prototype unit was designed to perform iris recognition faster and cheaper and provide a platform for demonstrating LANL capabilities in iris biometrics.

\section{Importance to LANL's Science and Technology Base and National R\&D Needs}

This project supports Los Alamos core competencies in bioscience and biotechnology as well as complex experimentation and measurement. A second-generation prototype unit will maintain LANL's visibility in this area and increase the Laboratory's ability to respond to initiatives.

\section{Scientific Approach and Results to Date}

Our original iris biometric prototype unit was delivered to the government sponsor, leaving us with no functioning units to demonstrate our capabilities. As a result of this LDRD project, we were able to construct and test a second generation unit. This instrument is smaller (by 30\%), cheaper (by 30\%), and faster (by 20\%) than the original unit.

\section{References}

1. A. Bertillon, Revue Scientifique 36, 3 (1885). 
2. A. Bertillon (translated by G. Muller), "Identification of Criminals," (AMS Press, New York, 1977).

3. F.H. Adler, "Physiology of the Eye," (Mosby, St. Louis, 1965); Also, R.A. Moses, Editor, "Adler's Physiology of the Eye," (E.V. Mosby, St. Louis, 1975).

4. A. Flom and A. Safir, "Iris Recognition System," U.S. Patent 4,641,349, February 3, 1987.

5. M. Hatamian and D.J. Anderson, "Noise Tolerance of a Video Eye Position Detector," in Proceedings, Frontiers of Engineering in Health Care 1982, A.R. Potvin and J.H. Potvin, Editors, pp. 313-316.

6. D. Miller, "Ophthalmology," (Houghton Mifflin, Boston, 1979).

7. D. Vaughan and T. Asbury, "General Ophthalmology," (Lange, Los Altos, CA, 1980).

8. M.J. Hogan, J.A. Alvarado, and J.E. Weddell, "Histology of the Human Eye'" (Saunders, Philadelphia, 1971).

9. B.S. Fine and M. Yanoff, "Ocular Histology," (Harper \& Row, NY, 1979).

10. M. Yanoff and B.S. Fine, "Ocular Pathology," (Harper \& Row, Phila., 1982).

11. R.S. Rodriguez-Sains, Ophthalmology 93, 661 (1986).

12. T.P. Dryja and D.M. Albert, Arch. Ophthalmol., 98, 1996 (1980).

13. R.G. Johnston, "Can Iris Patterns be Used to Identify People?," Chemical and Laser Sciences Division Annual Report, Los Alamos National Laboratory Report LA-12331-PR, 1991, pp. 81-86

14. F. Tennant, "The Rapid Eye Test to Detect Drug-Abuse," Postgraduate Medicine 84, 108 (1988).

15. F. Tennant, "Rapid Eye Test to Detect Drug Influence," (Veract, West Covina, CA, 1987).

16. M.B. Bener and F.H. O'Brien, "The Influence of Barbiturates on Various Forms of Nystagmus," Am J Opth 29, 1541 (1946).

17. A. Walser, A.B. Safran, P. Schulz, et al., "Effects of Small Doses of Bromazepam on Pupillary Function and on Flicker Perception of Normal Subjects," J Clin Psychopharm 7, 59 (1987).

18. S.T. Wasterman, A. Golz, F.S. Komorowski, et al., "Qualitative Measurement of Drugs," Laryngoscope 94, 165 (1984).

19. A.B. Safran, A. Walser, and A. Roth, et al., "Influence of Central Depressant Drugs on Pupil Function: an Evaluation with the Pupil Cycle Induction Test," Opthalmologica 183, 214 (1981). 
20. J.M. Stapleton, S. Gutherie, and M. Linnolla. "Effects of Alcohol and Other Psychotropic Drugs on Eye Movements: Relevance to Traffic Safety," J. Stud Alchohol 47, 426 (1986).

21. W.B. Pickworth, P. Welch, J.E. Henningfield, and E.J. Cone, "Opiate-Induced Pupillary Effects in Humans," Methods and Findings in Experimental and Clinical Pharmacology 11, 759 (1989).

22. A.M. Jones and R.T. Pivik, "Vestibular Activation, Smooth Pursuit Tracking, and Psychosis," Psychiatry Research 14, 291 (1985).

23. R.B. Lipton, D.L. Levy, P.S. Holzman, and S. Levin, "Eye Movement Dysfunctions in Psychiatric Patients: A Review," Schizophrenia Bulletin 9, 13 (1983).

24. R.J. Leigh and D.S. Zee, "The Neurology of Eye Movements" (Davis, Philadelphia, 1983).

25. S. Vogel, "In the Blink of an Eye," Discover, February, 1989, pp. 62-64.

26. Anonymous, "Look Me in the Eye," Discover, February, 1990, pp. 8-11.

\section{DISCLAIMER}

This report was prepared as an account of work sponsored by an agency of the United States Government. Neither the United States Government nor any agency thereof, nor any of their employees, makes any warranty, express or implied, or assumes any legal liability or responsibility for the accuracy, completeness, or usefulness of any information, apparatus, product, or process disclosed, or represents that its use would not infringe privately owned rights. Reference herein to any specific commercial product, process, or service by trade name, trademark, manufacturer, or otherwise does not necessarily constitute or imply its endorsement, recommendation, or favoring by the United States Government or any agency thereof. The views and opinions of authors expressed herein do not necessarily state or reflect those of the United States Government or any agency thereof. 